Canadian

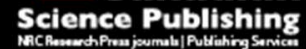

Canadian Journal of Microbiology Revue canadienne de de microbiologie

\title{
Tracking the relative concentration between Bacteroidales \\ DNA markers and culturable Escherichia coli in fecally polluted subtropical seawater: potential use in differentiating fresh and aged pollution
}

\begin{tabular}{|r|l|}
\hline Journal: & Canadian Journal of Microbiology \\
\hline Manuscript ID & cjm-2016-0241.R3 \\
\hline Danuscript Type: & Note \\
\hline Complete List of Authors: & $\begin{array}{l}\text { Liu, Rulong; Shanghai Ocean University, Shanghai Engineering Research } \\
\text { Center of Hadal Scicence and Technology, College of Marine Sciences; The } \\
\text { Hong Kong University of Science and Technology, Division of Life Science } \\
\text { Yeung, Leo T. C.; The Hong Kong University of Science and Technology, } \\
\text { Division of Life Science } \\
\text { Ho, Pui-Hei; The Hong Kong University of Science and Technology, } \\
\text { Division of Life Science } \\
\text { Lau, Stanley C.K.; The Hong Kong University of Science and Technology, } \\
\text { Division of Life Science; The Hong Kong University of Science and } \\
\text { Technology, Division of Environment }\end{array}$ \\
\hline Keyword: & \begin{tabular}{l} 
Bacteroidales, E. coli, decay, fecal pollution, age \\
\hline
\end{tabular} \\
\hline
\end{tabular}

\section{SCHOLARONE \\ Manuscripts}


Tracking the relative concentration between Bacteroidales DNA markers and culturable Escherichia coli in fecally polluted subtropical seawater: potential use in differentiating fresh and aged pollution

Rulong Liu, Leo T. C. Yeung, Pui-Hei Ho, Stanley C. K. Lau

Rulong Liu. Shanghai Engineering Research Center of Hadal Science and Technology, College of Marine Sciences, Shanghai Ocean University, Shanghai 201306, China; Division of Life Science, The Hong Kong University of Science and Technology, Clear Water Bay, Hong Kong (Email: rlliu@shou.edu.cn)

Leo T. C. Yeung and Pui-Hei Ho. Division of Life Science, The Hong Kong University of Science and Technology, Clear Water Bay, Hong Kong (Emails: L.T.C. Yeung, leoyeung13@gmail.com; P.H. Ho, nicoleho.nic@gmail.com)

Stanley C. K. Lau. Division of Life Science and Division of Environment, The Hong Kong University of Science and Technology, Clear Water Bay, Hong Kong (Email: scklau@ust.hk)

\section{"Corresponding author:}

Stanley C. K. Lau

Division of Life Science and Division of Environment, The Hong Kong University of Science and Technology, Clear Water Bay, Hong Kong Email: scklau@ust.hk;

Phone: +852-2358-7329; Fax: +852-2358-1559 


\begin{abstract}
Routine water quality monitoring practices based on the enumeration of culturable Escherichia coli provides no information about the source or age of fecal pollution. An emerging strategy is to use culturable E. coli and the DNA markers of Bacteroidales complementarily for microbial source tracking. In this study, we observed consistently in seawater microcosms of three different conditions that culturable $E$. coli decayed faster $\left(\mathrm{T}_{99}=\right.$ 1.14 - 4.29 day) than Bacteroidales DNA markers did $\left(\mathrm{T}_{99}=1.81-200.23\right.$ day).

Concomitantly, the relative concentration between Bacteroidales DNA markers and culturable E. coli increased over time in all treatments. Particularly, the increase during the early stage of the experiments (before $\mathrm{T}_{99}$ of $E$. coli was reached) was faster than during the later stage (after $\mathrm{T}_{99}$ of $E$. coli was attained). We propose that the tracking of the relative concentration between Bacteroidales DNA markers and culturable E. coli provides an opportunity to differentiate a pollution that is relatively fresh from one that has aged. This method, upon further investigation and validation, could be useful in episodic pollution events where the surge of E. coli concentration causes non-compliance to the single sample maximum criterion that mandates high frequency follow up monitoring.
\end{abstract}

Keywords: Bacteroidales, E. coli, decay, fecal pollution, age 
For decades, culturable Escherichia coli (cEC) served as an indicator of fecal pollution in freshwater (USEPA 2006) and seawater (HKEPD 2014). It is a common practice for routine water quality monitoring programs that the water of a given location is sampled and analyzed on a weekly or even monthly basis (HKEPD 2014; USEPA 2015). Very often non-compliance to water quality standard would not come to a regulatory agency's attention until the next scheduled monitoring. When monitoring is infrequent, it is often not known whether the non-compliance is due to a pollution incident that has occurred shortly prior to the monitoring or an incident that has occurred days or weeks before (Sokolova et al. 2012).

The differentiation of fresh and aged pollution can be useful for health risk assessment, since the persistence of fecal pathogens varies widely in the aquatic environment. For example, it took the intact cells of Salmonella enterica serovar Typhimurium $122 \mathrm{~h}$ to undergo $99 \%$ reduction of the initial concentration in freshwater under diurnal sunlight, and it only took the DNA of adenovirus $72 \mathrm{~h}$ and the intact cells of Camplyobacter jejuni $34 \mathrm{~h}$ to attain the same under identical conditions (Bae and Wuertz 2012). Contrarily, norovirus and the endospores of Bacillus have been reported to persist for weeks or longer (Boyle et al. 2008; Seitz et al. 2011). Ideally, the persistence of $\mathrm{cEC}$ as fecal indicator bacteria should be comparable to that of the most recalcitrant pathogens. Nevertheless, as the more labile pathogens deactivate more quickly, a pollution event that has occurred recently should carry pathogens of higher diversity and infectivity than an event that has aged. However, the concentrations of cEC obtained in routine water quality monitoring, as a function of input scale, population decay and dispersal, provide little information whether a pollution being detected is fresh or aged (Sokolova et al. 2012).

Another limitation of cEC counting-based routine water quality monitoring is the lack of information about the source(s) of fecal pollution (e.g. humans, farm animals and wildlife). This hinders not only the identification of the source of impairment (e.g. sewage discharge vs. farm runoff) but also the assessment of health risks, since different animal species often carry 
different variety of fecal pathogens (Harwood et al. 2014). Although DNA fingerprinting of cEC can be used for microbial source tracking, the broad host range of E. coli can limit its use in microbial source tracking (Savichtcheva and Okabe, 2006). In recent years, the host-specific 16S rRNA gene markers (DNA markers hereafter) of Bacteroidales have emerged as promising alternatives for microbial source tracking (Liu et al. 2012). A tiered approach that couples the monitoring of cEC count as an index of pollution level followed by PCR detection of Bacteroidales DNA markers as source identifier has been proposed (Noble et al. 2006; Liu et al. 2015).

Building upon the tiered approach of microbial source tracking, here we demonstrate using the data of the current study and a previous study (Table 1) that the monitoring of the relative concentrations between the DNA markers of Bacteroidales and cEC is potentially useful for the differentiation of a pollution incident that is aged from one that is relatively fresh. The persistence of fecal microbes is dependent on a number of intrinsic and extrinsic factors, such as the physiology and genetic diversity of the microbes and the prevailing environment conditions. It is a common practice to use $\mathrm{T}_{99}$ (i.e. the amount time required to attain $99 \%$ reduction of the initial concentration) as a metric for the persistence of fecal microbes in the aquatic environments (Bae and Wuertz 2012; Jenkins et al. 2012). Here we use $\mathrm{T}_{99}$ of $\mathrm{cEC}$ as a delimiter to differentiate fresh and aged pollution; we define pollution as relatively fresh when its associated cEC population is on decay towards $99 \%$ reduction of the initial concentration (i.e. before $\mathrm{T}_{99}$ is reached), and as aged when the reduction is $>99 \%$ (after $\mathrm{T}_{99}$ is reached).

In the current study, we conducted an outdoor experiment with two trials of a microcosm that was comprised of a $27 \mathrm{~L}$ glass aquarium filled with $19 \mathrm{~L}$ untreated seawater and $1 \mathrm{~L}$ raw sewage. Upon the adding of the raw sewage to the seawater at 9 am of the day that the experiment began $(0 \mathrm{~h})$, the microcosm was placed outdoor without obstruction to 
sunlight, receiving on average $13.49 \mathrm{MJm}^{-2}$ of global solar radiation each day with daily maximum intensity of UVA ranging from 11.3 to $61.0 \mathrm{Wm}^{-2}$ during the course of the experiment (Hong Kong Observatory). The total water level was $20 \mathrm{~cm}$ deep, allowing sunlight to penetrate to the bottom of the microcosm. Water temperature in the microcosm was maintained at ca. $26^{\circ} \mathrm{C}$ (typical for summer days in Hong Kong) using a run-through water jacket pumping from the sea surface. The microcosm was continuously aerated using $0.22 \mu \mathrm{m}$-filtered air to keep the seawater normoxic (dissolved oxygen concentration ca. $8 \mu \mathrm{g}$ $\mathrm{ml}^{-1}$ ), amidst the respiration of the fecal community. To reduce water evaporation, the microcosm was covered with a Dupont FEP-Teflon film (50 $\mu \mathrm{m}$ thick) that was reported to allow the transmission of $>96 \%$ of solar radiation (Teflon 1996). Water level and salinity in the microcosm was observed regularly. Water loss due to evaporation was replenished using autoclaved double-distilled water so as to maintain water salinity at $30 \pm 1 \%$. Further description of the microcosm conditions are provided in Supporting Information.

The experiment lasted for 4 days until the initial concentration of $\mathrm{cEC}$ had reduced by $>$ $99.9 \%$ (i.e. 3 log) (Fig. 1 and 2). During this period of time, triplicate water samples (200 ml each) were taken from the microcosm on the schedule specified in Table 1. The water samples were $0.22 \mu \mathrm{m}$ membrane-filtered. Bacterial cells captured on the membranes were subjected to the enumeration of $\mathrm{cEC}$ using CHROMagar ${ }^{\mathrm{TM}} \mathrm{ECC}$, and the determination of the copy numbers of the general (AllBac) and human-specific (HF) Bacteroidales DNA markers using SYBR $^{\circledR}$ Green dye-based qPCR (Liu et al. 2015). Further information of the procedure of DNA extraction, and the conditions and quality control of the qPCR assays can be found in Supporting Information.

At $0 \mathrm{~h}$ of the experiment, seawater in the two trial microcosms was observed carrying $3.40 \times 10^{5}-3.44 \times 10^{6} \mathrm{CFU} 100 \mathrm{ml}^{-1}$ of $\mathrm{cEC}, 4.73 \times 10^{9}-1.08 \times 10^{10}$ copy $100 \mathrm{ml}^{-1}$ of AllBac, and $5.07 \times 10^{8}-2.17 \times 10^{9}$ copy $100 \mathrm{ml}^{-1}$ of HF (Fig. $1 \& 2$ ). In trial one, the $\log _{10}$ transformed 
ratio of the concentrations between AllBac and cEC (AllBac:cEC hereafter) was 4.19 whereas that between HF and cEC (HF:cEC hereafter) was 3.29 (Fig. 1). In trial two, the values for AllBac:cEC and HF:cEC were 3.29 and 2.53, respectively (Fig. 2). These values are in line with what had been reported for human feces and sewage that AllBac was 2 to 6 orders of magnitude more abundant than $\mathrm{cEC}$, and that $\mathrm{HF}$ as a major Bacteroidales lineage was 1 to 2 orders of magnitude less abundant than AllBac (Gourmelon et al. 2010; Stoeckel et al. 2011).

The changes in the concentrations of cEC, AllBac and HF over the next 4 days were analyzed using the GInafit software package for the fitting of the data to decay models, and the determination of decay rate constants and $\mathrm{T}_{99}$ values (Geeraerd et al. 2005). The results of decay model fitting indicated for both microcosm trials of the experiment that $\mathrm{cEC}$ went on population decay immediately after $0 \mathrm{~h}$ whereas AllBac and HF exhibited a lag time of $>1$ day (i.e. a "shoulder" in the decay curves) before population decay (Fig. $1 \& 2$; Table 2). The decay of cEC, as observed using cultivation, was primarily associated with cell death and/ or the loss of culturability in viable cells (Green et al., 2011). Contrarily, the decay of Bacteroidales DNA markers, as observed using qPCR of target genes, was independent of the state of cellular viability or culturability. Solar radiation, particularly the UV spectrum, is strongly bactericidal. It can directly and indirectly (through reactive oxygen immediate) damage the nucleic acid, protein and lipids of bacterial cells, resulting in mutation, inactivation of metabolism, membrane damage, or death (Sinton et al. 2002). However, the effects of solar radiation on metabolic inactivation were quicker than on DNA or membrane damage, as shown for the bacterioplankton community in the Mediterranean coastal waters (Alonso-Saez et al. 2006). Therefore, we suggest that the differences between the time required for the onset of the decay of cEC (immediate) and Bacteroidales DNA markers $(>1$ day) can be in part explained as due to solar radiation having more immediate effect on the deactivation of metabolism (hence the decay of $\mathrm{cEC}$ ) than to the damaging of DNA and/or 
cell membrane (hence the loss of Bacteroidales DNA markers) (Liu et al. 2008).

Nonetheless, the specific decay pattern of each bacterial indicator varied considerably between trials (Fig. $1 \&$ 2; Table 2). For example, AllBac and HF had shorter "shoulder lengths" and more rapid decay in trial one than in trial two. The decay of cEC in trial one was log-linear for two days followed by a tail whereas the decay in trial two was biphasic with a relatively rapid but short $1^{\text {st }}$ phase and a slower but longer $2^{\text {nd }}$ phase. Biphasic decay is believed to be the effects of multiple environmental stresses (Bae and Wuertz 2009 and 2012). We suggest that such between-trial differences were due to the variations of one or more intrinsic or extrinsic factors associated with the experiment, including but not limited to weather conditions, and the genetic diversity and physiological status of the fecal microbes.

Despite the between-trial variations in decay pattern of individual indicator, the values of AllBac:cEC and HF:cEC exhibited a trend of increase over the four days of incubation in both trials. In trial one, the value of AllBac:cEC varied between 3.65 and 4.19 during the first $4 \mathrm{~h}$. Then it increased to 5.26 by the end of day one and further, by a smaller magnitude, to 5.94 in the next three days (Fig. 1). In trial two, the value of AllBac:cEC increased from 3.28 to 5.07 during the first $12 \mathrm{~h}$, and hovered between 4.34 and 4.87 towards the end of the experiment (Fig. 2). As a lineage within Bacteroidales (Seurinck et al. 2005), the changes in the concentration of HF and the value of HF:cEC mirrored those of AllBac and AllBac:cEC, respectively.

Generally, the values of AllBac:cEC and HF:cEC increased in relatively large magnitudes during the first day, as cEC decayed towards $99 \%$ reduction of the initial concentrations $\left(\mathrm{T}_{99}=1.13\right.$ day for trial one and 1.14 day for trial two) and the Bacteroidales DNA markers remained relatively recalcitrant (Fig. $1 \& 2$ ). After that, the magnitude of increase reduced when Bacteroidales DNA markers started to decay (trial one) or the decay of cEC started to enter the slower $2^{\text {nd }}$ phase (trial two). The fluctuations of the AllBac:cEC and 
HF:cEC values observed for the short intervals of sampling during the first few hours may be associated with the uneven distribution of the fecal microbes in the microcosms.

Many studies have reported that Bacteroidales DNA markers and cEC decayed at different rates under the same environmental condition. It is primarily attributed to the differences in the physiology of the two bacteria (e.g. E. coli being facultative anaerobic vs. Bacteroidales being strictly anaerobic) and the differences in the working principles of the detection methods (cultivation vs. PCR detection of DNA markers) (Green et al. 2011; Jeanneau et al. 2012). Based on the results of the microcosm experiment described above, we suggest that the differential decay between Bacteroidales DNA makers and cEC is potentially useful for estimating the status of a pollution event being detected. A fast increase in the relative concentration between Bacterodiales DNA markers and cEC may suggest a relatively fresh pollution (cEC associated with the pollution is decaying towards $99 \%$ reduction of the initial concentration) whereas a slow increase may suggest a pollution that has aged for a while (cEC population has decayed by $>99 \%$ of the initial). Nonetheless, the experiment was conducted under a single condition (i.e. outdoor for a few days, aerated) with a single source of $E$. coli and Bacteroidales (i.e. sewage). It was not known whether similar results would be obtained when experiments were conducted using other fecal sources and under different environmental conditions.

To corroborate our results, we re-analyzed the data of two seawater microcosms of our previous work that had fecal source and incubation setting different from the experiment discussed above (Table 1). The setup of the two microcosms is described in details in Liu et al. (2015). Briefly, the microcosms were kept under normoxic (dissolved oxygen ca. $8 \mu \mathrm{g} \mathrm{ml}^{-1}$ ) or hypoxic (dissolved oxygen $<1 \mu \mathrm{g} \mathrm{ml}^{-1}$ ) condition by purging the seawater with 0.22 $\mu \mathrm{m}$-filtered air or $\mathrm{N}_{2}$ gas (purity $>99.9 \%$ ). The seawater was $0.22 \mu \mathrm{m}$-filtered and autoclaved for the purpose of investigating the effects of normoxia and hypoxia on bacterial decay 
without the confounding effects of bacterial competition, viral lysis and protozoan grazing. Slurry of feces collected freshly from feral cows was spiked to each microcosm to a final concentration of ca. $0.01 \mathrm{~g}$ (w.t.) $\mathrm{ml}^{-1}$. The microcosms were maintained indoor under darkness at $26^{\circ} \mathrm{C}$ for 11 days until cEC had decayed by $>99.9 \%$ of the initial concentration. The concentrations of cEC, and AllBac and CF (the DNA marker for cow-associated Bacteroidales) were monitored over time (Table 1). Information about qPCR assay for the detection of CF can be found in Supporting Information.

AllBac decayed log-linearly under the hypoxic condition and in a biphasic manner under the normoxic condition with the $1^{\text {st }}$ phase accounted for $86.46 \%$ (trial one) and $99.03 \%$ (trial two) reduction of the initial concentrations (Table 2; see Liu et al. 2015 for the decay curves). The decay of CF was primarily log-linear, except in trial one of the normoxic treatment where biphasic decay was observed $\left(1^{\text {st }}\right.$ phase $=83.31 \%$ reduction $)$. cEC decayed in a biphasic manner in both treatments with the $1^{\text {st }}$ phase accounted for $>99.80 \%$ reduction of the initial concentration. Generally, cEC decayed at significantly higher rates than AllBac and CF did, as compared on the basis of the regression slopes $(\mathrm{p} \leq 0.005)$.

Concomitant with the differential decay was the relative concentrations between Bacteroidales DNA markers and cEC exhibiting a trend of increase over time (Fig. 3). We compared the magnitude of changes in the values of AllBac:cEC and CF:cEC before and after the cEC population in a microcosm had decayed by $99 \%$ of the initial. The $\mathrm{T}_{99}$ values of cEC ranged from 2.96 to 4.29 days in the two trials of the two microcosms (Table 2). To align these values with the monitoring schedule of the experiment (Table 1), we used day $0-4$ as the period that $\mathrm{cEC}$ was on decay towards $99 \%$ of the initial concentrations, and day $4-11$ as the period after. For the hypoxic treatment, the values of AllBac:cEC increased by the magnitude of 1.85 (trial one) and 1.68 (trial two) between day 0 and day 4 while the values of CF:cEC increased by 2.09 (trial one) and 1.72 (trial two) during the same period of time (Fig. 
3). Subsequently, between day 4 and 11, the increase was by smaller magnitudes of 0.48 (trial one) and 0.67 (trial two) for AllBac:cEC, and 0.58 (trial one) and 0.84 (trial two) for CF:cEC. Similar results were obtained for trial one of the normoxic treatment but not for trial two (Fig. 3). For trial one, the value of AllBac:cEC increased by the magnitude of 1.05 between day 0 and 4 , followed by a smaller magnitude of 0.38 between day 4 and 11 whereas the values of CF:cEC increased by 1.11 and 0.40 during the two periods, respectively. However, for trial two, the magnitude of increase during the period between day 0 and 4 (AllBac:cEC $=0.57$ and $\mathrm{CF}: \mathrm{cEC}=0.76$ ) were smaller than during the period after (AllBac:cEC $=1.02$ and $\mathrm{CF}: \mathrm{cEC}=0.81)$

The microcosms reported in Liu et al. (2015) and the current study together represent an array of fecal sources (sewage vs. cow) and environmental conditions (light vs. dark; normoxia vs. hypoxia) that are relevant to the marine environment of the subtropical Hong Kong. We have consistently observed in all microcosms that the decay of Bacteroidales DNA makers was generally slower than the loss of culturability in E. coli, and that concomitant with the differential decay was the relative concentrations between the two bacterial indicators increasing over time. Using $\mathrm{T}_{99}$ of $\mathrm{cEC}$ in a microcosm to delimit fresh and aged pollution, we observed in five of the six microcosms (except for the normoxic treatment in trial two of indoor experiment, Fig. 3) that the magnitudes of the increase in the relative concentration between Bacteroidales DNA makers and cEC (1.69 - 2.09) were larger during the period prior to $\mathrm{T}_{99}$ than the period after $(0.48-0.84)$. Nonetheless, the microcosm of trial two of the normoxic treatment would still have the relative concentration increased for a larger magnitude in the earlier stage than in the later stage of the experiment if the delimiter was shifted to the next sampling point (day 6) of the microcosm experiment.

Many regulatory agencies have established water quality criteria based on (i) maximum concentration of $E$. coli present in a single water sample, and (ii) geometric mean $/ 90^{\text {th }}$ 
percentile / statistical threshold value of $E$. coli concentrations in water samples collected over a period of time (USEPA 2006; HKEPD 2014). The single sample maximum criterion is important for waters that are monitored infrequently or prone to episodic pollution; in the event of non-compliance, follow-up monitoring with high sampling frequency would usually be in place. We propose that, upon successful validation, the tracking of the pattern of change in the relative concentration between Bacteroidales DNA makers and cEC during such follow-up monitoring (e.g. once per day) would provide an opportunity to estimate whether the pollution being detected is relatively fresh or aged - a fast increase in the relative concentration would suggest the former whereas a slow increase would suggest the latter. The method can be conveniently added to the tiered approach of pollution monitoring that others have proposed to implement microbial source tracking within the current regime of $E$. coli-based water quality monitoring (Noble et al. 2006; Reischer et al. 2008).

Whether $\mathrm{T}_{99}$ of $\mathrm{cEC}$ is a practical delimiter of fresh vs. aged pollution, and what magnitude of increase in the relative concentration is indicative of fresh or aged pollution need to be defined in further investigations under field conditions that include dilution and other environmental factors. Indeed, Bacteroidales was observed to decay faster in batch-type microcosms than in flow-through experiments in the field (Bae and Wuertz 2015 and references therein). The method that we propose relies on the monitoring of the change in the relative concentration between Bacteroidales DNA markers and $\mathrm{cEC}$, and is thus independent of the initial ratio of the two during the onset of a pollution event. Nonetheless, we have tested only two fecal sources. It would be useful for further investigations to include fecal sources that differ widely in the relative population sizes between Bacteroidales and E. coli and to include the monitoring of pathogen diversity in relation to the changes in the relative concentrations.

Emerging evidence indicates that fecal bacteria, including E. coli and Bacteroidales, are 
capable of persisting in environmental matrices such as sediment and submerged phyllosphere (Vierheilig et al. 2012; Weidhass et al. 2015). The cross reactivity of Bacteroidales DNA markers with non-target animal sources or even non-fecal source is another noteworthy problem (Lamendella et al. 2009; Vierheilig et al. 2012; Harwood et al. 2014). These issues concern all microbial source tracking studies, including the current one. In fact, the detection of CF reported in this study was performed using a newly designed primer to alleviate the effects of cross reactivity with non-target animal sources (Liu et al. 2015).

A previous study proposed the use of the ratio between the host-associated Bacteroidales DNA markers and culturable indicator bacteria (e.g. E. coli) for the apportionment of pollution to different animal sources (Wang et al. 2013). It was concluded that the apportionment would be distorted as the pollution aged, due to the differential decay between host-associated DNA markers and culturable indicator bacteria (Wang et al. 2013). The method that we propose in the study is indeed to capitalize on such differential decay. Therefore, further testing should also include the feces of multiple animal sources and evaluate whether it would possible to determine the status of the pollution (fresh vs. age) contributed by each source by tracking the concentration of each host-associated Bacteroidales DNA marker relative to cEC.

Others have proposed using viable or metabolically active Bacteroidales cells as the detection target to identify recent pollution, since the strictly anaerobic Bacteroidales are unlikely to survive for long in the aquatic environment (Green et al. 2011; Bae and Wuertz 2015). While these methods are potentially useful, they require additional procedures of reverse transcription of $16 \mathrm{~S}$ rRNA molecules (for metabolically active cells) or propidium monoazide treatment (for cells with intact membrane) prior to qPCR assays. In this study, we propose that qPCR detection of Bacteroidaes DNA markers (inclusive of cells that were viable or non-viable, and cells that were metabolically active or inactive) in reference to the 
decay of cEC can provide metrics to evaluate the status of a pollution event as relatively fresh or aged. This method is based upon our findings that cEC decayed at higher rates than Bacteroidales DNA makers did. Many studies have reported such differential decay, but there were also reports that Bacteroidales DNA markers decaying at higher rates than cEC or that the two bacterial indicators decaying at similar rates (Walters and Field 2009; Dick et al. 2010; Jeanneau et al. 2012; Ahmed et al. 2014). Such variations can potentially confound the monitoring method being proposed in this study. Nonetheless, the results in this study provide a foundation for further investigation and validation of method under different settings that involve other types of water (e.g. freshwater and estuarine) and fecal sources under a wider range of environmental conditions in other climate regions (e.g. temperate, tropical) in the lab and in the field. Ultimately, a modeling approach that incorporates hydrological parameters, prevailing environmental conditions, and the decay rates of Bacteroidales DNA markers and cEC would be required to implement the tracking of the relative concentrations of the two bacterial indicator for the differentiation between fresh and aged pollution.

\section{Acknowledgements}

We thank the Swire Institute of Marine Science for the provision of space and equipment. This study was supported by the General Research Fund (664012 and 661413) and the Direct Allocation Grant (DAG11SC03) to SCKL.

\section{References}

Ahmed, W., Gyawali, P., Sidhu J.P.S., and Toze, S. 2014. Relative inactivation of faecal indicator bacteria and sewage markers in freshwater and seawater microcosms. Lett. Appl. Microb. 59: 348-354 
Alonso-Saez, L., Gasol, J.M., Lefort, T., Hofer, T., Sommaruga, R. 2006. Effect of natural sunlight on bacterial activity and differential sensitivity of natural bacterioplankton groups in northwestern Mediterranean coastal waters. Appl. Environ. Microbiol. 72(9): 5806-5813.

Bae, S., and Wuertz, S. 2009. Rapid decay of host-specific fecal Bacteroidales cells in seawater as measured by quantitative PCR with propidium monoazide. Water. Res. 43: $4850-4859$

Bae, S., and Wuertz, S. 2012. Survival of host-associated Bacteroidales cells and their relationship with Enterococcus spp., Campylobacter jejuni, Salmonella enterica Serovar Typhimurium, and adenovirus in freshwater microcosms as measured by propidium aonoazide-quantitative PCR. Appl. Environ. Microbiol. 78(4):922-932

Bae, S., and Wuertz, S. 2015. Decay of host-associated Bacteroidales cells and DNA in continuous-flow freshwater and seawater microcosms of identifical experimental design and temperature as measured by PMA-qPCR and qPCR. Wat. Res. 70: 205-213

Boyle, M., Sichel, C., Fernandez-Ibaez, P., Arias-Quiroz, G. B., Iriarte-Punna, M., Mercado, A., Ubomba-Jaswa, E. and McGuigan, K. G. 2008. Bactericidal Effect of Solar Water Disinfection under Real Sunlight Conditions. Appl. Environ. Microbiol. 74(10):2997-3001

Dick, L.K., Stelzer, E., Bertke, E., Fong, D.L., Stoeckel, D.M. 2010. Relative decay of Bacteroidales microbial source tracking markers and cultivated Escherichia coli in freshwater microcosms. Appl. Environ. Microbiol. 76: 3255-3262

Geeraerd, A.H., Valdramidis, V.P., and Van Impe, J.F. 2005. GInaFiT, a freeware tool to assess non-log-linear microbial survivor curves. Int. J. Food Microbiol. 102(1): 95-105.

Gourmelon, M., Caprais, M.P., Mieszkin, S., Marti, R., Wéry, E., Jardé, M., et al. 2010. Development of microbial and chemical MST tools to identify the origin of the faecal 
pollution in bathing and shellfish harvesting waters in France. Water Res. 44(16):

4812-24.

Green, H.C., Shanks, O.C., Sivaganesan, M., Haugland, R. and Field, K.G. 2011. Differential decay of human faecal Bacteroides in marine and freshwater. Environ. Microbiol. 13(12): $3235-3249$.

Harwood V.J, Staley, C., Badgley, B.D., Borges, K., Korajkic, A. 2014. Microbial source tracking makers for detection of fecal contamination in environmental waters: relationships between pathogens and human health outcomes. FEMS Microbiology Reviews 38(1): 1-40

HKEPD. 2014. Beach water quality in Hong Kong 2014. Hong Kong Environmental Protection Department, Hong Kong SAR Government, China.

Jeanneau, L., Solecki, O., Wéry, N., Jardé, E., Gourmelon, M., Communal, P.Y. et al. 2012. Relative decay of fecal indicator bacteria and human-associated markers: a microcosm study simulating wastewater input into seawater and freshwater. Environ. Sci. Technol. 46(4): 2375-2382.

Jenkins, M.B., Endale, D.M., Fisher, D.S., Adams, M.P., Lowerance, R., Newton, G.L., Vellidis, G. 2102. Survival dynamics of fecal bacteria in ponds of agricultural waersheds of the Piedmont and coastal plain of Georgia. Wat. Res. 46: 176-86.

Lamendella, R., Santo Domingo, J.W., Yannarell, A.C., Ghosh, S. Di Giovanni, G., Mackie, R.I., Oerther, D.B. 2009. Evaluation of swine-specific PCR assays used for fecal source tracking and analysis of molecular diversity of swine-specific "Bacteroidales" populations. Appl. Environ. Microbiol. 75(18): 5787-96.

Liu, R., Chan, C.F., Lun, C.H.I., and Lau, S.C.K. 2012. Improving the performance of an end-point PCR assay commonly used for the detection of Bacteroidales pertaining to cow feces. Appl. Microbiol. Biotechnol. 93(4): 1703-13. 
Liu, R.L., Cheng, K.H.F., Wong, K., Cheng, S.C.S., and Lau, S.C.K. 2015. Differential utility of the Bacteroidales DNA and RNA markers in the tiered approach for microbial source tracking in subtropical seawater. Appl. Microbiol. Biotechnol. 99(13): 5669-81

Liu, Y., Gilchrist, A., Zhang, J. and Li, X.F. 2008. Detection of viable but nonculturable Escherichia coli O157:H7 bacteria in drinking water and river water. Appl. Environ. Microbiol. 74(5):1502-1507.

Noble, R.T., Griffith, J.F., Blackwood, A.D., Fuhrman, J.A., Gregory, J.B., Hernandez, X., et al. 2006. Multitiered approach using quantitative PCR to track sources of fecal pollution affecting Santa Monica Bay, California. Appl. Environ. Microbiol. 72(2):1604-1612.

Reischer, G.H.,Haider, J.M., Sommer, R., Stadler, H., Keiblinger, K.M., Hornek, R., Zerobin, W., Mach, R.L., and Farnleitner, A.H., 2008. Quantitative microbial faecal source tracking with sampling guided by hydrological catchment dynamics. Environ. Microb. 10: $2598-2608$.

Savichtcheva, O., Okabe, S., 2006. Alternative indicators of fecal pollution: relations with pathogens and conventional indicators, current methodologies for direct pathogen monitoring and future application perspectives. Water Res. 40 (13): 2463-2476.

Seitz, S.R., Leon, J.S., Schwab, K.J., Lyon, G.M., Dowd, M., McDaniels, M., Abdullhafid, G., Fernandez, M.L., Lindesmith, L.C., Baric, R., Moe, C.L. 2011. Norovirus infectivity in humans and persistence in water. Appl. Environ. Microbiol. 77(10): 6884-6888.

Seurinck, S., Defoird, T., Verstraete, W., and Siciliano, S.D. 2005. Detection and quantification of the human-specific HF183 Bacteroides 16S rRNA genetic marker with real-time PCR for assessment of human faecal pollution in freshwater. Environ. Microbiol. 7(2): 249-59. 
Sinton, L.W., Hall, C.H., Lynch, P.A., Davies-Colley, R.J. 2002. Sunlight inactivation of fecal indicator bacteria and bacteriophages from waste stabilization pond effluent in fresh and saline waters. Appl. Environ. Microbiol. 68: 1122-1131.

Sokolova, E., Aström, J., Pettersson, T.J.R., Bergstedt, O., and Hermansson, M. 2012. Decay of Bacteroidales genetic markers in relation to traditional fecal indicators for water quality modeling of drinking water sources. Environ. Sci. Technol. 46(2): 892-900.

Stoeckel, D.M., Stelzer, E.A., Stogner, R.W., and Mau, D.P. 2011. Semi-quantitative evaluation of fecal contamination potential by human and ruminant sources using multiple lines of evidence. Water Res. 45(10): 3225-44.

Teflon. 1996. Teflon ${ }^{\circledR}$ film Information Bulletin. 12/96, 240670C, DuPont company: U.S.A.

USEPA. 2006. Water quality standards for coastal recreation waters: using single sample maximum values in state water quality standard, EPA-823-F-06-013. United States Environmental Protection Agency.

USEPA. 2015. Citing online sources: Beach monitoring frequency. Available from http://watersgeo.epa.gov/beacon2/reports.html [accessed Aug 14 $\left.{ }^{\text {th }}, 2015\right]$.

Vierheilig, J., Farnleither, A.H., Kollanur, D., Blöschl, G., Reischer, G.H. 2012. High abundance of genetic Bacteroidales markers for total fecal pollution in pristine alphine soils suggests lack in specificity for feces. J. Microbiol Methods 88(3): 433-435.

Walters, S.P., Field, K.G. 2009. Survival and persistence of human and cattle-specific faecal Bacteroidales in freshwater microcosms. Environ. Microbiol. 11:1410-1421

Wang, D., Farnleitner, A.H., Field, K.G., Green, H.C., Shanks, O.C., and Boehm, A.B. 2013. Enterococcus and Escherichia coli fecal source apportionment with microbial source tracking genetic markers--is it feasible? Wat. Res. 47(18): 6849-6861 
Weidhaas, J., Mantha, S., Hair, E., Nayak, B., Harward, V.J. 2015. Evidence for extraintestinal growth of Bacteroidales originating from poultry litter. Appl. Environ. Microbiol. 81(1): 196-202.

\section{Supporting Information}

Materials and methods. Supporting information for microcosm conditions, DNA extraction, qPCR conditions, performance characteristics of qPCR assays, alleviating the effects of PCR inhibitors present in DNA samples.

Table S1. Primers for qPCR enumeration of the 16S rRNA gene markers of total (AllBac), human-specific (HF) and cow-specific (CF) Bacteroidales as well as the cytochrome b gene of the barnacle Balanus amphitrite serving as DNA recovery control (DRC).

Table S2. Performance characteristics of qPCR assays. 


\section{Figure legends:}

Figure 1. Trial 1 of the microcosm conducted in the current study under sunlight with raw sewage spiked to untreated seawater. Data shown in (a) and (b) are changes in mean concentrations \pm 1 S. D. $(n=3)$ of the $16 \mathrm{~S}$ rRNA gene markers of total (AllBac) and human-associated (HF) Bacteroidales, and culturable E. coli (cEC) during the course of the experiment. Curve fitting was determined using the GInafit software. The dotted line in (b) indicates the reduction of $\mathrm{cEC}$ concentration by $99 \%$ of the initial. The mean concentrations of AllBac and HF relative to that of cEC at each time point are $\log _{10}$-transformed and shown as AllBac:cEC and HF:cEC in (c) with the vertical dotted line indicating the time required for cEC to attain $99 \%$ reduction of the initial concentration.

Figure 2. Trial 2 of the microcosm conducted in the current study under sunlight with raw sewage spiked to untreated seawater. Data shown in (a) and (b) are changes in mean concentrations \pm 1 S. D. $(\mathrm{n}=3)$ of the $16 \mathrm{~S}$ rRNA gene markers of total (AllBac) and human-associated (HF) Bacteroidales, and culturable E. coli (cEC) during the course of the experiment. Curve fitting was determined using the GInafit software. The dotted line in (b) indicates the reduction of $\mathrm{cEC}$ concentration by $99 \%$ of the initial. The mean concentrations of AllBac and HF relative to that of cEC at each time point are $\log _{10}$-transformed and shown as AllBac:cEC and HF:cEC in (c) with the vertical dotted line indicating the time required for cEC to attain $99 \%$ reduction of the initial concentration.

Figure 3. The re-analysis of the data of the microcosm experiment published in Liu et al. 
(2015). The microcosms containing autoclaved seawater spiked with cow feces were incubated under darkness, and were purged with air and $\mathrm{N}_{2}$ to maintain normoxic and hypoxic conditions, respectively. The experiments were conducted in two trials with different batches of seawater and cow feces. Data shown are the $\log _{10}$-transformed mean concentrations $(n=3)$ of the 16S rRNA gene markers of total (AllBac) and cow-associated (CF) Bacteroidales relative to that of culturable E. coli (i.e. AllBac:cEC and CF:cEC) at each time point. The vertical dotted lines indicate the time required for $\mathrm{cEC}$ to attain $99 \%$ reduction of the initial concentration in each microcosm. 
1 Table 1. Conditions of microcosm experiments. The results in this study are derived from the data of an experiment (one microcosm) that was 2 conducted during the current study, and the re-analysis of the data of an experiment (two microcosms) that was reported in Liu et al. (2015). All 3 microcosms were conducted in two trials.

\begin{tabular}{|c|c|c|c|c|c|c|c|}
\hline \multirow{2}{*}{$\begin{array}{c}\text { Microcosm } \\
\text { No. }\end{array}$} & \multicolumn{5}{|c|}{ Conditions } & \multirow[b]{2}{*}{ Monitoring schedule } & \multirow[b]{2}{*}{ Reference } \\
\hline & Fecal source & Seawater & Light & Oxygen & Water temp. $\left({ }^{\circ} \mathrm{C}\right)$ & & \\
\hline 1 & Raw sewage & Untreated & Sunlight ${ }^{*}$ & Normoxic $\S$ & 26 & $0,2,4,6,12$, and $24 \mathrm{~h} ; 1.5,2,3$, and $4 \mathrm{~d}$ & Current study \\
\hline $\begin{array}{l}2 \\
3\end{array}$ & Cow & $\begin{array}{l}\text { Filtered \& } \\
\text { autoclaved }\end{array}$ & Absent $^{\dagger}$ & $\begin{array}{c}\text { Normoxic }^{\S} \\
\text { Hypoxic }^{ף}\end{array}$ & 26 & $0,1,2,4,6,8$ and $11 \mathrm{~d}$ & $\begin{array}{l}\text { Liu et al. } \\
(2015)\end{array}$ \\
\hline
\end{tabular}

5

* Sunlight through a $50 \mu$ m-thick Dupont FEP-Teflon film

†Wrapped in black plastic lining

${ }^{\S}$ Dissolved oxygen $=\sim 8 \mu \mathrm{g} \mathrm{mL}^{-1}$

${ }^{\top}$ Dissolved oxygen $=\sim 1 \mu \mathrm{g} \mathrm{mL}^{-1}$ 
Table 2. Decay rates of culturable E. coli (cEC), and the 16S rRNA gene markers of general (AllBac), human-associated (HF) and cow-associated (CF) Bacteroidales in seawater microcosms. Each microcosm was conducted in two trials. Data were fitted to decay models using the GInafit software (B: biphasic; L: log-linear; S: shoulder; T: tail). Data shown for biphasic decay include decay rate constants for the first $\left(\mathrm{k}_{1}\right)$ and second $\left(\mathrm{k}_{2}\right)$ phase $\left(\mathrm{day}^{-1}\right)$. Log-linear decay involves only one decay constant $\left(\mathrm{k}_{1}\right)$. For decay curves having a "shoulder" preceding the decay, "shoulder length" (SL) is provided to indicate the length of the period (day). The time required for a bacterial indicator to attain $99 \%$ reduction of the initial concentration is indicated by

$16 \mathrm{~T}_{99}$ (day).

\begin{tabular}{|c|c|c|c|c|c|c|c|c|c|c|c|c|c|c|c|c|c|}
\hline \multirow{2}{*}{$\begin{array}{l}\text { Microcosm } \\
\text { No. }\end{array}$} & \multirow{2}{*}{ Conditions } & \multirow{2}{*}{ Trial } & \multicolumn{5}{|c|}{$\mathrm{cEC}$} & \multicolumn{5}{|c|}{ AllBac } & \multicolumn{5}{|c|}{$\mathrm{HF} / \mathrm{CF}$} \\
\hline & & & Model & SL & $\mathrm{k}_{1}$ & $\mathrm{k}_{2}$ & $\mathrm{~T}_{99}$ & Model & SL & $\mathrm{k}_{1}$ & $\mathrm{k}_{2}$ & $\mathrm{~T}_{99}$ & Model & $\mathrm{SL}$ & $\mathrm{k}_{1}$ & $\mathrm{k}_{2}$ & $\mathrm{~T}_{99}$ \\
\hline \multirow{2}{*}{1} & Normoxic & 1 & L-T & - & 4.08 & - & 1.14 & S-L-T & 1.50 & 47.76 & - & 1.62 & S-L-T & 1.52 & 16.8 & - & 1.81 \\
\hline & + Sunlight & 2 & B & - & 23.04 & 1.20 & 1.13 & S-L & 3.48 & 7.92 & - & 4.07 & S-L & 3.25 & 6.48 & - & 3.96 \\
\hline \multirow[t]{2}{*}{$2 *$} & Normoxic & 1 & B & - & 1.19 & $<0.01$ & 2.96 & B & - & 0.73 & $<0.01$ & - & B & - & 0.89 & $<0.01$ & 28.62 \\
\hline & + Darkness & 2 & B & - & 1.09 & $<0.01$ & 3.68 & B & - & 0.59 & $<0.01$ & 51.28 & $\mathrm{~L}$ & - & 0.40 & - & 11.54 \\
\hline \multirow[t]{2}{*}{$3 *$} & Hypoxic & 1 & B & - & 1.59 & 0.14 & 4.07 & L & - & 0.19 & - & 24.26 & $\mathrm{~L}$ & - & 0.16 & - & 200.23 \\
\hline & +Darkness & 2 & B & - & 1.27 & $<0.01$ & 4.29 & $\mathrm{~L}$ & - & 0.19 & - & 13.42 & $\mathrm{~L}$ & - & 0.04 & - & 113.08 \\
\hline
\end{tabular}

*the values shown were re-calculated from published data in Liu et al. (2015), with the permission from Applied Microbiology and Biotechnology. 

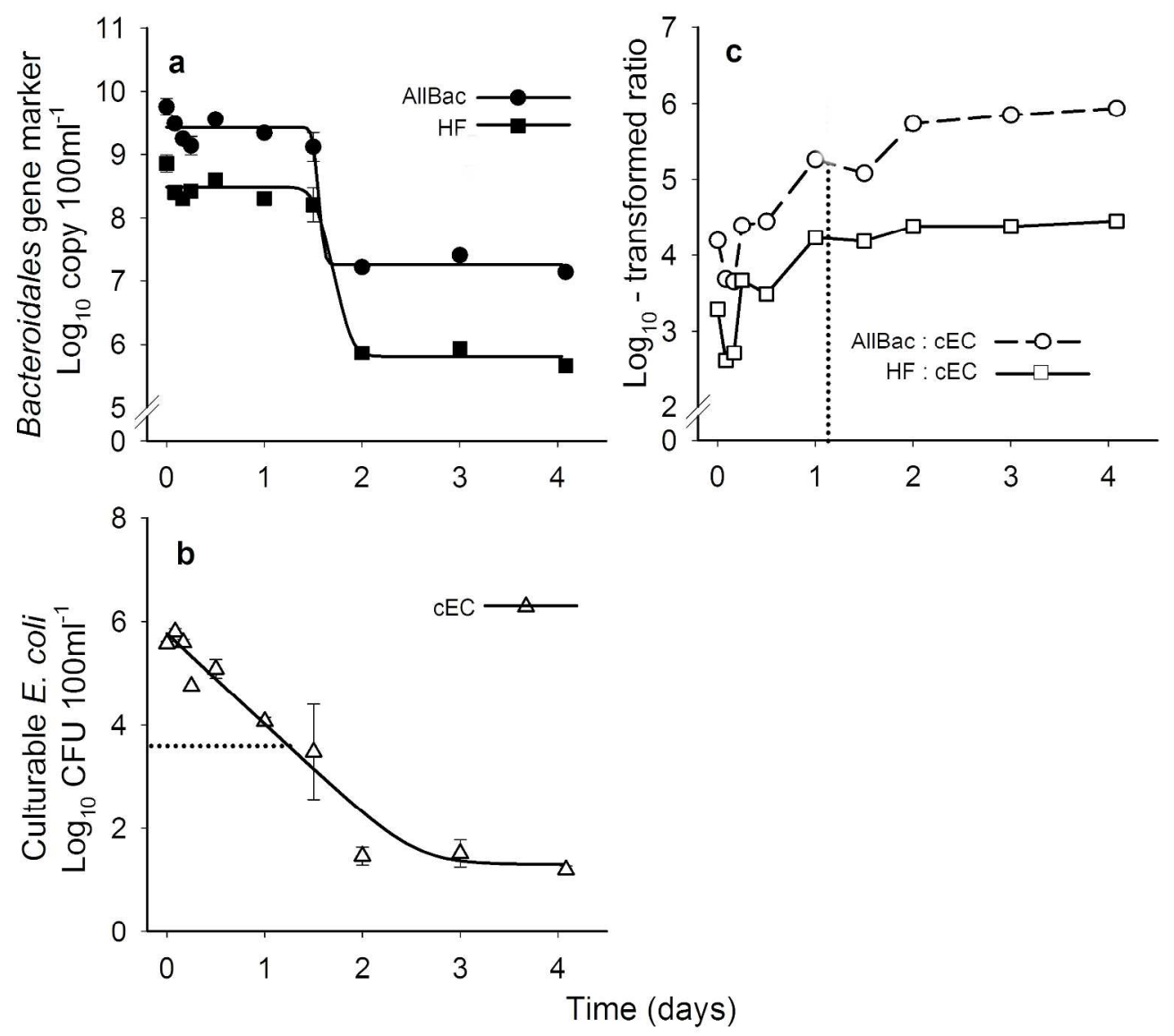

Figure 1. Trial 1 of the microcosm conducted in the current study under sunlight with raw sewage spiked to untreated seawater. Data shown in (a) and (b) are changes in mean concentrations \pm 1 S. D. $(n=3)$ of the $16 \mathrm{~S}$ rRNA gene markers of total (AllBac) and human-associated (HF) Bacteroidales, and culturable $E$. coli (cEC) during the course of the experiment. Curve fitting was determined using the GInafit software. The dotted line in (b) indicates the reduction of cEC concentration by $99 \%$ of the initial. The mean concentrations of AllBac and HF relative to that of CEC at each time point are log10-transformed and shown as AllBac:cEC and HF:CEC in (c) with the vertical dotted line indicating the time required for cEC to attain 99 $\%$ reduction of the initial concentration.

$253 \times 225 \mathrm{~mm}(300 \times 300 \mathrm{DPI})$ 

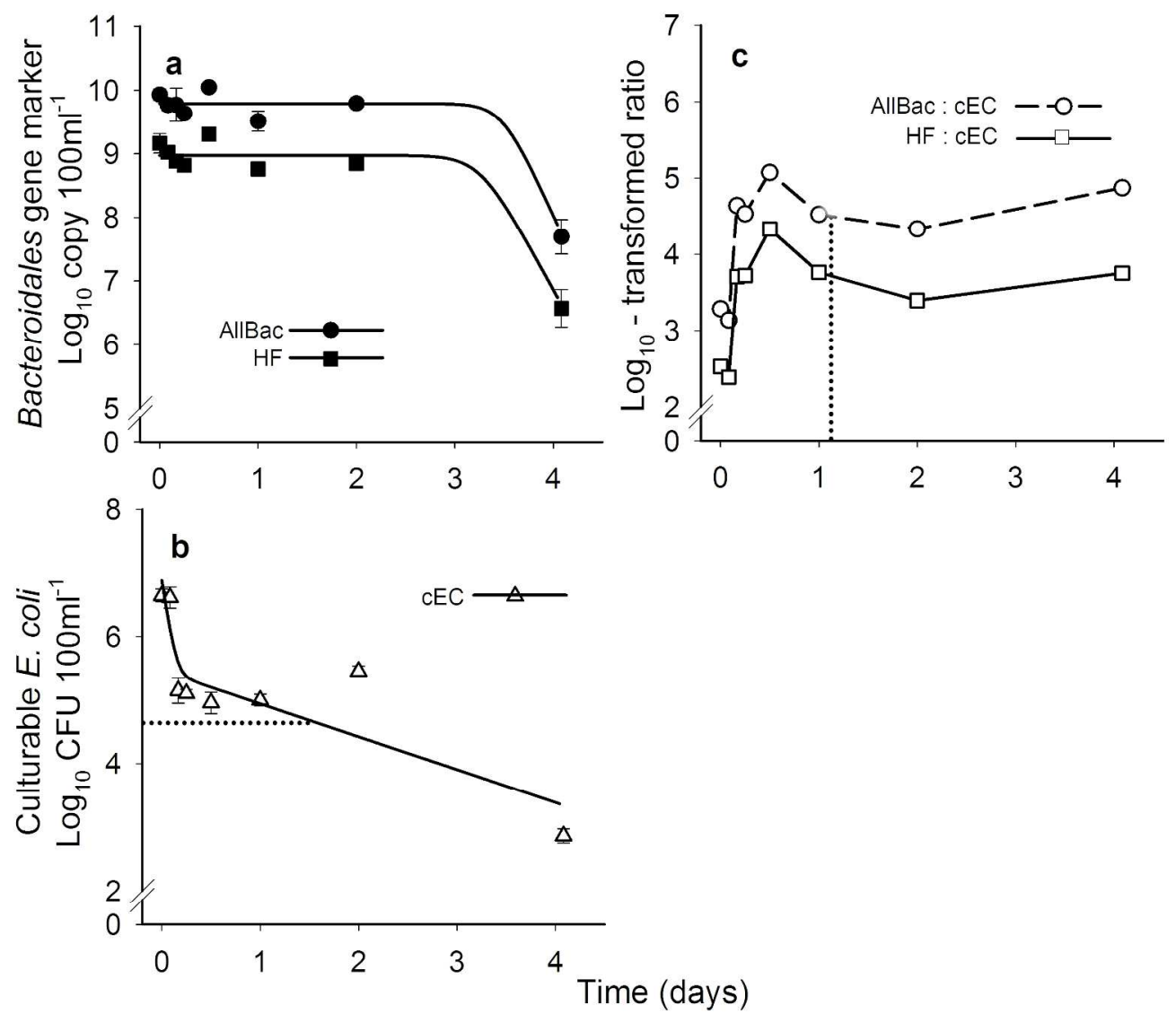

Figure 2. Trial 2 of the microcosm conducted in the current study under sunlight with raw sewage spiked to untreated seawater. Data shown in (a) and (b) are changes in mean concentrations $\pm 1 \mathrm{~S}$. D. $(n=3)$ of the $16 \mathrm{~S}$ rRNA gene markers of total (AllBac) and human-associated (HF) Bacteroidales, and culturable $E$. coli (cEC) during the course of the experiment. Curve fitting was determined using the GInafit software. The dotted line in (b) indicates the reduction of cEC concentration by $99 \%$ of the initial. The mean concentrations of AllBac and HF relative to that of CEC at each time point are log10-transformed and shown as AllBac: cEC and HF:cEC in (c) with the vertical dotted line indicating the time required for cEC to attain 99 $\%$ reduction of the initial concentration.

$252 \times 218 \mathrm{~mm}(300 \times 300 \mathrm{DPI})$ 


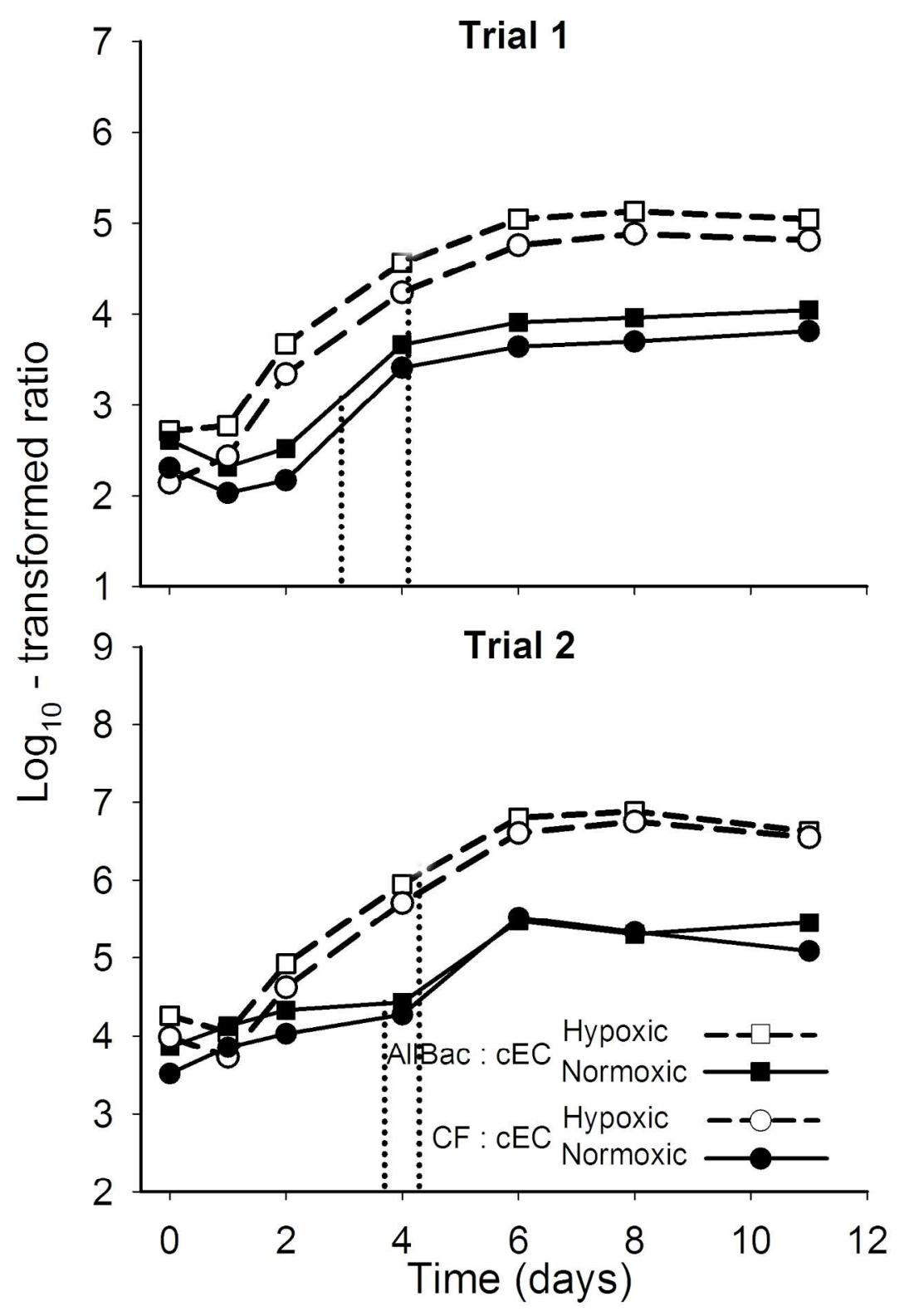

Figure 3. The re-analysis of the data of the microcosm experiment published in Liu et al. (2015). The microcosms containing autoclaved seawater spiked with cow feces were incubated under darkness, and were purged with air and N2 to maintain normoxic and hypoxic conditions, respectively. The experiments were conducted in two trials with different batches of seawater and cow feces. Data shown are the log10transformed mean concentrations $(n=3)$ of the 16S rRNA gene markers of total (AllBac) and cowassociated (CF) Bacteroidales relative to that of culturable E. coli (i.e. AllBac:CEC and CF:cEC) at each time point. The vertical dotted lines indicate the time required for CEC to attain $99 \%$ reduction of the initial concentration in each microcosm.

$149 \times 213 \mathrm{~mm}(300 \times 300 \mathrm{DPI})$ 


\section{Material and Methods}

\section{Supporting Information}

3

\section{Microcosm conditions}

In the current study, we conducted an outdoor experiment with two trials of a microcosm that was comprised of a $27 \mathrm{~L}$ glass aquarium filled with $19 \mathrm{~L}$ untreated seawater and $1 \mathrm{~L}$ raw sewage. The aquarium was cleaned (household bleach) and rinsed (autoclaved double-distilled water) prior to the filling of seawater freshly collected off the coast of Hong Kong (Table 1). The seawater had no detectable Bacteroidales DNA marker or cEC as determined using the methods described in the main text of the manuscript. Upon the adding of the raw sewage to the seawater at 9 am of the day that the experiment began $(0 \mathrm{~h})$, the microcosm was placed outdoor without obstruction to sunlight, receiving on average $13.49 \mathrm{MJm}^{-2}$ of global solar radiation each day with daily maximum intensity of UVA ranging from 11.3 to $61.0 \mathrm{Wm}^{-2}$ during the course of the experiment (Hong Kong Observatory). The total water level was $20 \mathrm{~cm}$ deep and had turbidity of 10.42 NTU in trial one of the experiment and 24.40 NTU in trial two after the addition of sewage, allowing sunlight to penetrate to the bottom of the microcosm. These turbidity values were within the range of the annual average of 7.5 - 29.5 NTU reported for Hong Kong waters (HKEPD 2014).

Water temperature in the microcosm was maintained at ca. $26{ }^{\circ} \mathrm{C}$ (typical for summer days in Hong Kong) using a run-through water jacket pumping from the sea surface. The microcosm was continuously aerated using $0.22 \mu \mathrm{m}$-filtered air to keep the seawater normoxic (dissolved oxygen concentration ca. $8 \mu \mathrm{g} \mathrm{ml}^{-1}$ ), amidst the respiration of the fecal community. The DO concentration fell within the range of $5-10 \mu \mathrm{g} \mathrm{ml}^{-1}$ typically observed for the surface waters in Hong Kong (HKEPD 2014). To reduce water evaporation, the microcosm was covered with a Dupont FEP-Teflon film ( $50 \mu \mathrm{m}$ thick) that was reported to allow the transmission of $>96 \%$ of 
26 solar radiation (Teflon 1996). Water level and salinity in the microcosm was observed regularly.

27 Water loss due to evaporation was replenished using autoclaved double-distilled water so as to 28 maintain water salinity at $30 \pm 1 \%$. Water $\mathrm{pH}$ in the microcosm varied between 7.7 and 8.0

29 during the experiment.

\section{DNA extraction}

Each water sample collected from the microcosms was divided into two equal volumes

33 for the enumeration of cEC using CHROMagar ${ }^{\mathrm{TM}} \mathrm{ECC}$ and Bacteroidales DNA gene markers in 34 both viable and non-viable cells using SYBR ${ }^{\circledR}$ Green dye-based qPCR following the procedures

35 described in Liu et al. (2015). The samples for qPCR were filtered through $0.22 \mu \mathrm{m}$

36 polycarbonate membranes. Cells captured were lysed using lysozyme and achromopeptidase.

37 Each cell lysate was spiked with a $345 \mathrm{bp}$ PCR-amplified cytochrome b gene of the barnacle

Balanus amphitrite $\left(10^{7}\right.$ copies $\left.\mu \mathrm{l}^{-1} ; 10 \mu \mathrm{l}\right)$ as DNA recovery control (DRC) (Gregoris et al. 2009).

Total DNA was extracted using the phenol-chloroform method (Liu et al. 2010) and the final volume of the extract were $100 \mu \mathrm{l}$ for each sample. The copy numbers of DRC and the general (AllBac) and human-specific (HF) Bacteroidales DNA markers in each DNA sample were quantified using previously reported qPCR assays (Table S1). All values of Bacteroidales DNA marker concentration reported in this manuscript were corrected using the recovery rate of DRC:

44 Conc. of DNA marker detected / (Conc. of DRC detected / Conc. of DRC spiked).

qPCR conditions

All qPCR assays were performed in duplicate $20 \mu 1$ reactions, each containing $4 \mu 1$ of 
cycles were: initial denaturation $\left(95^{\circ} \mathrm{C}\right)$ for $10 \mathrm{~min}$, followed by 40 cycles of denaturation $\left(95^{\circ} \mathrm{C}\right)$

50 for $15 \mathrm{sec}$, and annealing and extension $\left(60^{\circ} \mathrm{C}\right.$ for $\mathrm{HF}, \mathrm{CF}$, and DRC; $62{ }^{\circ} \mathrm{C}$ for AllBac) for 1 min. Standard curves were constructed using plasmids of each Bacteroidales DNA marker

52 described below.

\section{Performance characteristics of qPCR assays}

Standards curves of Ct value vs. DNA marker copy number were constructed using serially diluted linearized plasmids of each marker. Eight and four standard curves were obtained for CF and HF, respectively, while twelve were obtained for AllBac and DRC. Three replicate reactions were used for each copy number of a DNA marker on a standard curve. As a measure of the variability of $\mathrm{Ct}$ values among replicates, the coefficient of variations (CV) was calculated using the mean and standard deviation of the $\mathrm{Ct}$ values of the three replicates $(\mathrm{CV}=$ standard deviation / mean $\times 100 \%$ ). The mean of all CV values obtained for the standard curves of each DNA marker was $<0.81 \%$ (Table S1).

The dynamic range of the standard curves of each DNA marker was $2 \times 10^{1}-2 \times 10^{6}$ copy per reaction for AllBac and CF, $4-4 \times 10^{5}$ copy per reaction for HF, and $2 \times 10^{2}-2 \times 10^{7}$ copy per reaction for DRC. Within their dynamic range, the linearity $\left(\mathrm{R}^{2}=0.988-1.000\right)$ and amplification efficiency $\left(10^{(-1 / \text { slope })}-1=90.0-101.8 \%\right)$ of the standard curves fell within the acceptable range of $0.985-1.000$ and 90 - $110 \%$, respectively (Eurogentec) (Table S1).

\section{PCR inhibitors present in DNA samples}

All DNA samples were diluted so as to alleviate the effects of PCR inhibitors. The level of dilution required was determined on the basis of the difference in the $\mathrm{Ct}$ values between two successive 10 -fold dilutions of a sample $(\Delta \mathrm{Ct})$. Inhibition was considered significant when $\Delta \mathrm{Ct}$ 
73 was $<3$ (Dick et al. 2010). Ten-fold dilution (0.1x) was applied to all samples in study. 
74 Table S1. Primers for qPCR enumeration of the 16S rRNA gene markers of general (AllBac), human-specific (HF) and cow-specific

75 (CF) Bacteroidales as well as the cytochrome b gene of the barnacle Balanus amphitrite serving as DNA recovery control (DRC).

76

\begin{tabular}{|c|c|c|c|c|c|c|}
\hline Marker & Organism (gene) & Primer & Sequence $\left(5^{\prime}-3^{\prime}\right)$ & $\begin{array}{l}\text { Annealing } \\
\text { temperature }\left({ }^{\circ} \mathrm{C}\right)\end{array}$ & $\begin{array}{l}\text { Amplicon } \\
\text { size (bp) }\end{array}$ & Reference \\
\hline AllBac & $\begin{array}{l}\text { All Bacteroidales } \\
\text { (16S rRNA) }\end{array}$ & $\begin{array}{l}\text { AllBac-296F } \\
\text { AllBac-412R }\end{array}$ & $\begin{array}{l}\text { GAGAGGAAGGTCCCCCAC } \\
\text { CGCTACTTGGCTGGTTCAG }\end{array}$ & 62 & 116 & Layton et al. 2006 \\
\hline $\mathrm{HF}$ & $\begin{array}{l}\text { Human-specific } \\
\text { Bacteroidales } \\
\text { (16S rRNA) }\end{array}$ & $\begin{array}{l}\text { HF183F } \\
\text { Bac265R }\end{array}$ & $\begin{array}{l}\text { ATCATGAGTTCACATGTCCG } \\
\text { TACCCCGCCTACTATCTAATG }\end{array}$ & 60 & 82 & Seurinck et al. 2005 \\
\hline $\mathrm{CF}$ & $\begin{array}{l}\text { Cow-specific } \\
\text { Bacteroidales } \\
\text { (16S rRNA) }\end{array}$ & $\begin{array}{l}\text { CF128F } \\
\text { CF302R }\end{array}$ & $\begin{array}{l}\text { CCAACYTTCCCGWTACTC } \\
\text { TCAGAACCCCTAGACATCG }\end{array}$ & 60 & 174 & $\begin{array}{l}\text { Bernhard and Field } 2000 \\
\text { Liu et al. } 2015\end{array}$ \\
\hline DRC & $\begin{array}{l}\text { Barnacle Balanus } \\
\text { amphitrite } \\
\text { (cytochrome b) }\end{array}$ & $\begin{array}{l}\text { CY-F } \\
\text { CY-R }\end{array}$ & $\begin{array}{l}\text { GGACACTGCATGCTAATGGA } \\
\text { AGGCAGCAGCCATAGTCAAG }\end{array}$ & 60 & 144 & Gregoris et al. 2009 \\
\hline
\end{tabular}

77 
79 Table S2. Performance characteristics of qPCR assays. Four standard curves were obtained for HF, eight were obtained for CF whereas 80 twelve were obtained for AllBac and DRC. All of the curves of the same DNA marker resulted in the same dynamic range. The values 81 of linearity $\left(\mathrm{R}^{2}\right)$, slope and amplification efficiency were determined for each curve using data obtained within the dynamic range; data 82 shown for each marker are the range and mean (in parenthesis) of all curves. The mean efficient of variation (CV) for each marker was 83 calculated using $\mathrm{Ct}$ values from all curves.

84

\begin{tabular}{|c|c|c|c|c|}
\hline & \multicolumn{4}{|c|}{ DNA Marker } \\
\hline & AllBac & $\mathrm{CF}$ & $\mathrm{HF}$ & DRC \\
\hline $\begin{array}{l}\text { No. of standard } \\
\text { curves }\end{array}$ & 12 & 8 & 4 & 12 \\
\hline Mean CV $(\%)$ & 0.63 & 0.41 & 0.81 & 0.53 \\
\hline $\begin{array}{l}\text { Dynamic range } \\
\left.\text { (copies reaction }^{-1}\right)\end{array}$ & $2 \times 10^{1}$ & $\times 10^{6}$ & $4-4 \times 10^{5}$ & $2 \times 10^{2}-2 \times 10^{7}$ \\
\hline $\mathrm{R}^{2}$ & $\begin{array}{r}0.987-0.998 \\
(0.996)\end{array}$ & $\begin{array}{r}0.999-1.000 \\
(0.999)\end{array}$ & $\begin{array}{r}0.994-0.999 \\
(0.996)\end{array}$ & $\begin{array}{r}0.994-0.999 \\
(0.998)\end{array}$ \\
\hline $\begin{array}{l}\text { Slope } \\
\text { (-ve values) }\end{array}$ & $\begin{array}{r}3.30-3.59 \\
(3.46)\end{array}$ & $\begin{array}{r}3.20-3.59 \\
(3.58)\end{array}$ & $\begin{array}{r}3.34-3.51 \\
(3.40)\end{array}$ & $\begin{array}{r}3.32-3.58 \\
(3.43)\end{array}$ \\
\hline $\begin{array}{l}\text { Amplification } \\
\text { efficiency (\%) }\end{array}$ & $\begin{array}{r}90.0-101.8 \\
(94.6)\end{array}$ & $\begin{array}{r}90.0-90.3 \\
(90.1)\end{array}$ & $\begin{array}{r}92.9-99.1 \\
(97.1)\end{array}$ & $\begin{array}{r}90.2-100.0 \\
(95.6)\end{array}$ \\
\hline
\end{tabular}




\section{References for supporting materials}

Bernhard, A.E., Field, K.G. 2000. A PCR assay to discriminate human and ruminant feces on the basis of host differences in Bacteroides-Prevotella genes encoding 16S rRNA. Appl. Environ. Microbiol. 66:4571-4574

Dick, L.K., Stelzer, E., Bertke, E.E., Fong, D.L., Stoeckel, D.M. 2010. Relative decay of Bacteroidales microbial source tracking markers and cultivated Escherichia coli in freshwater microcosms. Appl. Environ. Microbiol. 76(10):3255-62.

Eurogentec. Citing online sources: qPCR Guide. Available from http://www.eurogentec.com/uploads/qPCR-guide.pdf [accessed on 21st September, 2015].

Gregoris, T.B.D., Borra, M., Biffali, E., Bekel, T., Burgess, J.G., Kirby, R.R., et al. 2009. Construction of an adult barnacle (Balanus amphitrite) cDNA library and selection of reference genes for quantitative RT-PCR studies. BMC Mol. Biol. 10(1): 62.

HKEPD. 2014. Beach water quality in Hong Kong 2014. Hong Kong Environmental Protection Department, Hong Kong SAR Government, China.

Layton, A., McKay, L., Williams, D., Garrett, V., Gentry, R., Sayler, G., et al. 2006. Development of Bacteroides 16S rRNA gene TaqMan-based real-time PCR assays for estimation of total, human, and bovine fecal pollution in water. Appl. Environ. Microbiol. 72(6): 4214-4224.

Liu, R., Chiang, M.H.Y., Lun, C.H.I., Qian, P.Y., Lau S.C.K. 2010. Host-specific 16S rRNA gene markers of Bacteroidales for source tracking of fecal pollution in the subtropical coastal seawater of Hong Kong. Wat. Res. 44: 6164 -6174 
103 Liu, R.L., Cheng, K.H.F., Wong, K., Cheng, S.C.S. and Lau, S.C.K. 2015. Differential utility of the Bacteroidales DNA and RNA 104 markers in the tiered approach for microbial source tracking in subtropical seawater. Appl. Microbiol. Biotechnol. 99(13):5669-

105 81

106 Seurinck, S., Defoird, T., Verstraete, W. and Siciliano, S.D. 2005. Detection and quantification of the human-specific HF183

107 Bacteroides 16S rRNA genetic marker with real-time PCR for assessment of human faecal pollution in freshwater. Environ. Microbiol. 7(2): 249-59.

109 Teflon. 1996. Teflon ${ }^{\circledR}$ film Information Bulletin. 12/96, 240670C, DuPont company: U.S.A. 